\title{
ANALISIS INVESTASI ASING LANGSUNG DI INDONESIA
}

\author{
Oleh: \\ Mainita ${ }^{1}$ \\ Dosen tetap Universitas Muhammadiyah Jambi ${ }^{1}$ \\ mainitaita@gmail.com \\ Ahmad Soleh ${ }^{2}$ \\ Dosen Tetap Muhammadiyah Jambi² \\ mas.soleh@yahoo.com
}

Ringkasan

Investasi merupakan salah satu instrument penting dan motor penggerak dalam pembangunan, karena investasi merupakan langkah awal dalam pembangunan ekonomi. Pada negara sedang berkembang investasi sangat dibutuhkan dan mempunyai peran penting dalam mempercepat pembangunan karena merupakan alat dalam meningkatkan pertumbuhan pendapatan dan lapangan pekerjaan, peningkatan teknologi dan pembangunan sosial ekonomi.

Tujuan dari penelitian ini adalah menganalisis Investasi asing langsung di Indonesia dan menganalisis beberapa faktor yang mempengaruhinya. Data yang digunakan dalam penelitian ini adalah data sekunder (time series) dengan menggunakan metode analisis deskriptif kualitatif dan deskriptif kuantitatif.

Hasil penelitian menunjukkan bahwa terdapat perkembangan atau peningkatan investasi yang cukup tunggi terhadap pertumbuhan investasi asing di Indonesia. Dan menunjukkan bahwa variabel nilai tukar, peranan perdagangan Internasional dan ketimpangan pendapatan berpengaruh sifnifikan terhadap investasi asing di Indonesia dalam periode penelitian.

Kata Kunci : Investasi Asing Langsung, Determinan

\section{PENDAHULUAN}

Pembangunan ekonomi yang berhasil tidak semata-mata diukur pada tingkat pertumbuhan ekonomi yang tinggi dan berkelanjutan, tetapi sama pentingnya adalah bagaimana menciptakan pembangunan dan pertumbuhan yang berkualitas serta berkelanjutan (sustainable development) sehingga tingkat kesejahteraan masyarakat meningkat. Pembangunan ekonomi tidak hanya menuntut adanya peningkatan pendapatan per kapita atau pertumbuhan yang tinggi saja, tetapi meliputi jauh lebih banyak aspek salah satunya pemerataan pendapatan serta berkurangnya kemiskinan. Makin baik semuanya itu, semakin berkualitas pembangunan dan pertumbuhan ekonomi yang dicapai.

Modal merupakan pendorong pembangunan ekonomi, penanaman modal atau investasi merupakan langkah awal kegiatan produksi. Pada posisi semacam ini investasi pada hakekatnya juga merupakan langkah awal kegiatan pembangunan ekonomi. Dinamika 
penanaman modal mempengaruhi tinggi rendahnya pertumbuhan ekonomi, mencerminkan marak atau lesunya perekonomian.

Sebagai negara berkembang, Indonesia membutuhkan dana yang cukup besar untuk melaksanakan pembangunan, hal ini sebagai upaya untuk mengejar ketertinggalan dari negaranegara maju, baik di kawasan regional maupun kawasan global. Disamping menggali sumber pembiayaan dalam negeri, pemerintah juga mengundang sumber pembiayaan luar negeri, salah satunya adalah Penanaman Modal Asing Langsung (Foreign Direct Investment).

Investasi asing langsung merupakan salah satu alat untuk meningkatkan pertumbuhan pendapatan dan lapangan pekerjaan, peningkatan teknologi, pembangunan sosial-ekonomi yang pararel pada perbaikan distribusi pendapatan dan pengurangan kemiskinan terutama pada negara sedang berkembang. Kebijakan ekonomi suatu negara harus cukup atraktif terhadap Investasi asing langsung agar dapat memberikan dampak yang baik pada pengurangan kemiskinan dan ketimpangan pendapatan.

Indonesia sangat membutuhkan investasi asing untuk menunjang pertumbuhan ekonomi maupun perluasan tenaga kerja, upaya untuk menarik investor asing sudah dilakukan oleh pemerintah, diantaranya dengan menerapkan beberapa kebijakan penting secara efektif untuk menggenjot investasi. Kebijakan dibidang kepastian hukum, pelayanan terpadu satu pintu, paket-paket insentif pemerintah seperti penyederhanaan mekanisme perizinan, undang-undang perburuhan, iklim investasi yang kondusif dan pemangkasan birokrasi.

Saat ini, kesempatan dalam berinvestasi di Indonesia semakin terbuka, terutama bagi penanaman modal asing. Keterbukaan ini sejalan dengan era perdagangan bebas yang dihadapi penanaman modal asing didorong bagi kegiatan ekspor dan kegiatan yang belum dapat dilakukan oleh modal dan teknologi dalam negeri. Kesadaran akan perlunya penanaman modal asing didasarkan atas harapan akan dapat memacu pertumbuhan dan pemerataan ekonomi, meningkatkan peran aktif masyarakat serta memperluas lapangan kerja serta kesempatan kerja.

Indonesia sebagai negara berkembang membutuhkan peranan penanaman modal asing langsung untuk menunjang perekonomian. Keputusan investasi oleh pihak asing dipengaruhi oleh beberapa faktor fundamental makro ekonomi suatu negara. Faktor fundamental tersebut digambarkan melalui inflasi, tingkat suku bunga dan nilai tukar mata uang rupiah (eliza;2013).

(Cahyanto;2012) dalam penelitiannya mengungkapkan bahwa naiknya tingkat inflasi di Indonesia akan menyebabkan penurunan tingkat aliran modal asing yang masuk ke Indonesia karena para penanam modal asing akan menunda atau menghentikan kegiatan investasinya di 
Indonesia. Dari latar belakang yang telah diraikan diatas maka tujuan dari penelitian ini adalah untuk menganalisis pengaruh tingkat inflasi, Kurs, peranan perdagangan internasional terhadap PDB, suku bunga, pertumbuhan ekonomi dan ketimpangan pendapatan terhadap aliran investasi asing langsung di Indonesia.

\section{TINJAUAN PUSTAKA}

\section{Teori Investasi}

Investasi merupakan tindakan investor untuk menginvestasikan dana dengan tujuan mendapatkan keuntungan yang berupa tingkat pengembalian (return on investment). Investasi dapat juga dibedakan antara investasi dalam negeri atau penanaman Modal Dalam Negeri (PMDN) dan investasi asing/ Penanaman Modal Asing (PMA). PMDN merupakan investasi yang dilakukan oleh investor dalam negeri, sementara PMA merupakan investasi yang dilakukan investor asing dengan menanamkan modalnya kepada proyek investasi di indonesia.

Penanaman modal asing adalah penanaman modal yang dilakukan oleh orang asing (foreigner) secara langsung berdasarkan ketentuan Undang-Undang No.1 Tahun 1967 dan yang digunakan menjalankan perusahaan di Indonesia, dalam arti pemilik modal secara langsung menanggung resiko dari penanaman modal tersebut.

Investasi asing di Indonesia dapat dilakukan dalam dua bentuk, Yaitu investasi portofolio dan investasi langsung. Investasi portofolio dilakukan melalui pasar modal, dengan instrumen surat berharga seperti saham dan obligasi. Sedangkan investasi langsung dikenal dengan Penanaman Modal Asing, merupakan bentuk investasi dengan jalan membangun, membeli total atau mengakuisisi perusahaan.

\section{Investasi Asing Langsung}

Investasi asing langsung merupakan investasi dimana investor asing dapat langsung berinvestasi dengan membeli secara langsung suatu aktiva keuangan. Investasi ini merupakan aset-aset riil yang melibatkan aset berwujud, misalkan pembelian aset produktif, pendirian pabrik, pembukaan pertambangan, pembukaan perkebunan dan lainnya. Investasi asing secara langsung selalu dikaitkan adanya keterlibatan secara langsung dari pemilik modal dalam kegiatan pengelolaan modal, pihak investor langsung terlibat dalam pengelolaan usaha dan bertanggung jawab secara langsung apabila terjadi suatu kerugian.

\section{Faktor-Faktor yang mempengaruhi investasi asing langsung}

Aliran investasi pada suatu negara dipengaruhi oleh beberapa faktor baik internal maupun eksternal, adapun beberapa faktor yang dapat mempengaruhi investasi asing langsung: 


\section{a. Inflasi}

Definisi singkat dari inflasi adalah kecenderungan dari harga-harga untuk naik atau meningkat secara umum dan terus-menerus. Inflasi didasarkan atas parah tidaknya inflasi dibedakan sbb:
a. Inflasi ringan (di bawah $10 \%$ setahun)
b. Inflasi sedang (antara $10-30 \%$ setahun)
c. Inflasi berat (antara $30-100 \%$ setahun)
d. Hiperinflasi (di atas $100 \%$ setahun)

Pengaruh antara inflasi terhadap kegiatan investasi memiliki hubungan yang negatif, dimana tingkat inflasi yang tinggi akan menurunkan tingkat investasi itu sendiri. Sebaliknya tingkat inflasi yang rendah akan menyebabkan biaya investasi menjadi murah sehingga akan merangsang investasi asing langsung.

\section{b. Nilai Tukar Rupiah terhadap USD}

Pengaruh tingkat kurs pada investasi terjadi melalui sisi permintaan dan penawaran. Dalam jangka pendek, penurunan tingkat nilai tukar akan mengurangi investasi melalui pengaruh negatifnya pada absorbs domestic, karena penurunan tingkat kurs ini akan menyebabkan nilai riil aset masyarakat yang disebabkan kenaikan tingkat harga-harga secara umum dan selanjutnya akan menurunkan permintaan domestik masyarakat. Gejala diatas pada tingkat perusahaan direspon dengan penurunan alokasi modal pada investasi. Pada sisi penawaran, pengaruh aspek pengalihan pengeluaran akan merubah tingkat kurs pada investasi relatif tidak menentu.

\section{c. Peranan Perdagangan Internasional}

Peranan perdagangan internasional dapat dihitung sebagai rasio dari neraca perdagangan, jumlah ekspor dikurang impor terhadap PDB negara tersebut.

$$
\text { Peranan Perdag.Int }=\frac{(\mathrm{X}-\mathrm{M})}{\mathrm{PDB}} \times 100 \%
$$

Keterangan :

$$
\begin{array}{ll}
\mathrm{X} & =\text { Ekspor } \\
\mathrm{M} & =\text { Impor } \\
\mathrm{PDB} & =\text { Produk Domestik Bruto }
\end{array}
$$

Interpretasinya semakin tinggi indeksnya maka semakin besar pengaruh perdagangan internasional pada aktivitas domestik dan semakin kuat perekonomian negara tersebut. Selain meningkatkan cadangan valas, manfaat lain dari perdagangan internasional adalah dalam 
bentuk efek langsung terhadap pertumbuhan output di dalam negeri. Bagi negara-negara yang ekonomi atau produksi mereka berorientasi ke pasar eksternal, seperti di Asia Tenggara dan Asia Timur atau negara-negara industri baru (Newly Industrialized Countries), peningkatan permintaan dunia terhadap produk-produk mereka akan memberikan dorongan positif terhadap pertumbuhan produksi dalam negeri dan juga akan berdampak pada pertumbuhan investasi baik dari dalam negeri maupun luar negeri.

Penawaran ekspor dipengaruhi oleh penanaman modal asing (PMA). Peningkatan PMA secara tidak langsung akan meningkatkan Industrialisasi. Sebagai akibatnya, jumlah barang yang diproduksi akan meningkat. Hubungan yang positif ini memang masih menjadi perdebatan oleh sebagian pengamat. Hal ini disebabkan oleh peluang terjadinya penanaman modal asing sangat tergantung dan dipengaruhi oleh kebijakan negara penerima (host country).

\section{d. Suku Bunga}

Kebijakan tingkat suku bunga dalam negeri merupakan bagian dari upaya pemerintah untuk meningkatkan akumulasi modal dalam berbagai sektor pembangunan. Chow (2008) mengungkapkan bahwa peningkatan modal di negara berkembang belakangan ini adalah sebagai akibat rendahnya tingkat suku bunga di negara maju, dengan kata lain tingkat suku bunga internasional dan tingkat suku bunga domestik memiliki pengaruh terhadap peningkatan investasi asing langsung. Sadono sukirno (2000) mengemukakan bahwa apabila tingkat suku bunga lebih besar dari pada tingkat pengembalian modal maka investasi tidak akan dilakukan oleh investor. Cahyanto (2012) dalam penelitiannya menjelaskan pengaruh dari tingkat suku bunga adalah positif dan signifikan terhadap penanaman modal asing di Indonesia periode 2005-2011.

\section{e. Pertumbuhan Ekonomi}

Perdebatan mengenai keterkaitan antara pertumbuhan ekonomi dan investasi asing langsung sebenarnya sudah terjadi sejak lama. pada satu sisi investasi asing langsung dipercaya memberikan pengaruh positif terhadap pertumbuhan ekonomi negara tujuan Effendi dan Soemantri (2003). Dampak positif ini terjadi karena adanya transfer teknologi dan keahlian manajerial, pengenalan teknologi produksi yang baru serta akses ke jaringan internasional. Untuk negara yang sedang berkembang, masuknya investasi asing langsung juga berarti adanya kemudahan untuk memperoleh pinjaman lunak. Sementara itu argumentasi negatif menyatakan bahwa kehadiran investasi asing langsung dapat mengganggu stabilitas ekonomi negara tujuan Germidis (1977). 


\section{f. Ketimpangan Pendapatan}

Ketimpangan Pendapatan adalah suatu kondisi dimana distribusi pendapatan yang diterima masyarakat tidak merata. Ketimpangan ditentukan oleh tingkat pembangunan, heterogenitas etnis, ketimpangan juga berkaitan dengan kediktatoran dan pemerintah yang gagal menghargai property rights (Glaeser, 2006).

\section{METODE PENELITIAN}

Penelitian ini menggunakan metode deskriptif kualitatif dan kuantitatif dengan menggunakan data sekunder (time series) dan dengan menggunakan tehnik dokumentasi. Sementara alat analisis yang digunakan dalam penelitian ini dengan menggunakan model pertumbuhan dan regresi linier berganda. Model pertumbuhan digunakan untuk menganalisis kondisi dari variabel yang ada dalam penelitian sementara model regresi digunaan untuk melihat pengaruh variabel yang mempengaruhi investasi penanaman modal asing. Adapun kedua model tersebut adalah sebagai berikut:

$$
X_{i}=\frac{X_{t}-X_{t-1}}{X_{t-1}} \times 100 \%
$$

Keterangan :

$\mathrm{X}_{\mathrm{i}} \quad=$ Pertumbuhan Variabel

$\mathrm{X}_{\mathrm{t}} \quad=$ Data tahun ke $\mathrm{t}$

$\mathrm{X}_{\mathrm{t}-1}=$ Data_tahun sebelumnya

$$
\mathrm{X}_{\mathrm{i}}=\mathrm{X}_{\mathrm{i}(1)+\ldots \ldots . .+\mathrm{X}_{\mathrm{i}(\mathrm{n})}}
$$

$\mathrm{n}$

Keterangan :

$\overline{\mathrm{X}}_{\mathrm{i}} \quad=$ Rata-Rata

$\mathrm{X}_{\mathrm{i}(1)} \quad=$ Data pertumbuhan variabel tahun ke-1

$\mathrm{X}_{\mathrm{i}(\mathrm{n})}=$ Data pertumbuhan variabel tahun ke-n

$\mathrm{n} \quad=$ Jumlah data observasi

dan selanjutnya...

$\operatorname{logFDI}=\alpha+\beta_{1} \operatorname{Inf}+\beta_{2} \log$ Kurs $+\beta_{3}$ Trade $+\beta_{4} \mathrm{sb}+\beta_{5} \mathrm{Y}+\beta_{6} \mathrm{gi}+\mathrm{e}$

Keterangan :

FDI $\quad=$ Investasi Asing Langsung

Inf $\quad=$ Inflasi

Kurs $\quad=$ Kurs Tengah Rupiah terhadap USD

Trade $\quad=$ Perdagangan Internasional

$\mathrm{sb} \quad=$ Suku Bunga

$\mathrm{Y} \quad=$ Pertumbuhan ekonomi

gi $\quad=$ Indeks gini/ ketimpangan pendapatan 


\begin{tabular}{|c|c|}
\hline$\alpha$ & $=$ Konstanta \\
\hline$\beta 1, \beta 2, \beta 3$ & $=$ koefisien elastisitas \\
\hline 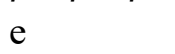 & $=$ Variabel Penganggu (error term) \\
\hline
\end{tabular}

\section{HASIL PENELITIAN}

Dari hasil analisis data dapat diperoleh hasil sebagai berikut:

\section{Tabel 1.Hasil Analisis Regresi Linier Berganda}

\begin{tabular}{|c|c|c|c|c|}
\hline \multicolumn{5}{|c|}{$\begin{array}{l}\text { Dependent Variable: LOG(FDI) } \\
\text { Method: Least Squares } \\
\text { Date: } 25 / 12 / 2019 \text { Time: 07:02 } \\
\text { Sample: } 19902017 \\
\text { Included observations: } 28\end{array}$} \\
\hline Variable & Coefficient & Std. Error & $\mathrm{t}$-Statistic & Prob. \\
\hline INF & -0.004782 & 0.017080 & -0.279994 & 0.7827 \\
\hline LOG(KURS) & 1.120475 & 0.338458 & 3.310532 & 0.0039 \\
\hline TRADE & 0.035227 & 0.010576 & 3.330842 & 0.0037 \\
\hline $\mathrm{SB}$ & -0.037487 & 0.041036 & -0.913499 & 0.3731 \\
\hline $\mathrm{Y}$ & -0.027807 & 0.095531 & -0.291077 & 0.7743 \\
\hline GI & 21.30479 & 3.499897 & 6.087262 & 0.0000 \\
\hline $\mathrm{C}$ & 0.255602 & 4.303953 & 0.059388 & 0.9533 \\
\hline R-squared & 0.948019 & \multirow{7}{*}{\multicolumn{2}{|c|}{$\begin{array}{l}\text { Mean dependent var } \\
\text { S.D. dependent var } \\
\text { Akaike info criterion } \\
\text { Schwarz criterion } \\
\text { Hannan-Quinn criter. } \\
\text { Durbin-Watson stat }\end{array}$}} & 17.47903 \\
\hline Adjusted R-squared & 0.930692 & & & 1.495772 \\
\hline S.E. of regression & 0.393782 & & & 1.205460 \\
\hline Sum squared resid & 2.791163 & & & 1.546745 \\
\hline Log likelihood & -8.068244 & & & 1.300118 \\
\hline F-statistic & 54.71355 & & & 1.517674 \\
\hline Prob(F-statistic) & 0.000000 & & & \\
\hline
\end{tabular}

Dari hasil pengolahan data diatas dapat dibuat formulasi sebagai berikut

$\log$ FDI $=0,256-0,005$ Inf $+1,220 \operatorname{logKurs}+0,035$ Trade $-0.037 \mathrm{Sb}-0,028 \mathrm{Y}+21,305 \mathrm{GI}$

$$
\begin{array}{lllll}
(0,783) \quad(0,004) \quad(0,004) \quad(0,373) \quad(0,774) \quad(0,00001)
\end{array}
$$

\section{Koefisien Determinasi $\left(\mathbf{R}^{2}\right)$}

Koefisien determinasi $\left(\mathrm{R}^{2}\right)$ mencerminkan besarnya pengaruh perubahan variabelvariabel bebas (independent Variables) dalam menjelaskan perubahan pada variabel terikat (dependent variable) secara bersama-sama dengan tujuan untuk mengukur kebenaran dan kebaikan hubungan antar variabel dalam model yang digunakan. Besarnya nilai $\mathrm{R}^{2}$ adalah antara 0 hingga $1\left(0<\mathrm{R}^{2}<1\right)$, dimana jika koefisien mendekati 1 , maka model tersebut dikatakan baik karena semakin dekat hubungan antara variabel bebas dengan variabel tidak bebasnya. 
Nilai R squared sebesar 0,948, berarti 94,8\% prediksi investasi asing langsung dapat dijelaskan oleh keenam variabel bebas seperti inflasi, kurs, peranan perdagangan internasional, suku bunga, pertumbuhan ekonomi dan ketimpangan pendapatan, sedangkan sisanya 5,2\% dipengaruhi oleh sebab-sebab lain diluar model.

\section{Uji f dan Uji t Statistik}

Uji statistik untuk menguji pengaruh Inflasi, kurs, peranan perdagangan internasional, suku bunga, pertumbuhan ekonomi dan ketimpangan pendapatan secara bersama-sama digunakan uji f statistik. Untuk menunjukkan apakah variabel bebas secara bersama-sama mempunyai pengaruh terhadap variabel dependen berdasarkan hasil penelitian pada tabel 5.1 diketahui nilai Probability (f statistic) sebesar 0,0000001 yang berarti lebih kecil dari derajat kesalahan sebesar 0,05 (5\%) dan dilihat dari hasil uji $\mathrm{f}$ berarti $\mathrm{H}_{0}$ ditolak karena $\mathrm{f}$ hitung $>\mathrm{f}$ tabel pada taraf signifikansi 5\% dengan diperoleh $\mathrm{f}$ tabel $=34,36$ dan $\mathrm{f}$ hitung $=54,71$ dengan demikian inflasi, kurs, peranan perdagangan internasional, suku bunga, pertumbuhan ekonomi, dan ketimpangan pendapatan secara bersama-sama berpengaruh signifikan dalam memprediksi aliran investasi asing langsung di Indonesia pada tahun 1990-2014.

Untuk menguji signifikansi masing-masing variabel bebas dalam mempengaruhi variabel terikat dilakukan uji t yang dapat dilihat pada tabel 5.1 diatas, secara parsial uji t dari keenam variabel bebas yang mempengaruhi secara signifikan investasi asing langsung di Indonesia pada tahun 1990-2014 adalah nilai tukar (kurs), peranan perdagangan internasional terhadap PDB dan ketimpangan pendapatan. Nilai tukar (kurs) berpengaruh secara positif dan signifikan, artinya ketika rupiah terdepresiasi sebesar 1\% maka akan meningkatkan aliran investasi asing langsung sebesar 1,12\%. Hal ini ditunjukkan dengan nilai t hitung sebesar 3,31 dan nilai probabilitasnya 0,004 lebih kecil dari alpha 0,05 , dengan demikian hipotesis alternatif diterima.

Variabel bebas selanjutnya yang mempengaruhi aliran investasi asing langsung secara parsial adalah peranan perdagangan internasional terhadap PDB. Berpengaruh positif dan signifikan, hal ini ditunjukkan dengan t hitung sebesar 3,33 lebih besar dari t tabel dengan alpha 0,05 dan nilai probabilitasnya 0,004 lebih kecil dari alpha 0,05. Dengan demikian hipotesis alternatif diterima artinya tingginya peranan perdagangan internasional terhadap PDB dapat mempengaruhi masuknya aliran investasi asing langsung di indonesia, jika peranan perdagangan meningkat sebesar 1\% maka akan meningkatkan aliran investasi asing langsung sebesar 0,04\%. 
Variabel ketimpangan pendapatan (indeks gini) secara parsial juga berpengaruh positif dan signifikan terhadap aliran Investasi Asing Langsung di Indonesia, terlihat dari nilai t hitung 6,09 dan nilai probabilitasnya 0,00001 lebih kecil dari alpha 0,05. Maka hipotesis alternatif diterima artinya tingkat ketimpangan pendapatan mempengaruhi aliran investasi asing langsung di Indonesia, jika ketimpangan pendapatan meningkat 1\% maka akan meningkatkan investasi asing langsung sebesar $21,3 \%$.

Sedangkan variabel bebas yang tidak berpengaruh signifikan secara parsial terhadap investasi asing langsung di Indonesia tahun 1990-2014 yaitu variabel Inflasi dilihat dari nilai probabilitynya 0,783 lebih besar dari alpha 0,05 . Variabel inflasi bernilai negatif dan tidak signifikan artinya tinggi rendahnya tingkat inflasi tidak mempengaruhi aliran investasi asing langsung.

Variabel suku bunga secara parsial juga tidak berpengaruh signifikan terhadap investasi asing langsung, terlihat dari nilai probabilitas sebesar 0,373 lebih besar dari alpha 0,05. Suku bunga negatif dan tidak signifikan artinya tinggi rendahnya suku bunga tidak mempengaruhi besarnya aliran investasi asing langsung di Indonesia.

Kemudian variabel bebas selanjutnya yang juga tidak berpengaruh secara parsial terhadap investasi asing langsung yaitu pertumbuhan ekonomi terlihat dari nilai probabilitasnya sebesar 0,774 lebih besar dari alpha 0,05. Koefisien variabel Pertumbuhan ekonomi bernilai negatif dan tidak signifikan artinya tinggi rendahnya pertumbuhan ekonomi tidak mempengaruhi tinggi rendahnya aliran investasi asing langsung di indonesia.

Berdasarkan analisis dalam uraian di atas dari keenam variabel independen tersebut bahwa variabel yang berpengaruh signifikan pada investasi asing langsung adalah nilai tukar (kurs), peranan perdagangan internasional terhadap PDB dan ketimpangan pendapatan. Sedangkan variabel yang tidak signifikan yaitu inflasi, suku bunga dan pertumbuhan ekonomi.

Selanjutnya dalam penelitian ini dilakukan Uji Asumsi Klasik, hasil dari uji tersebut adalah sebagai berikut:

1. Dari hasil multikolinieritas diperoleh hasil sebagai berikut:

Variance Inflation Factors

Date: 25/12/2019 Time: 07:12

Sample: 19902017

Included observations: 28

\begin{tabular}{llll}
\hline \hline Variable & $\begin{array}{l}\text { Coefficient } \\
\text { Variance }\end{array}$ & $\begin{array}{l}\text { Uncentered } \\
\text { VIF }\end{array}$ & $\begin{array}{l}\text { Centered } \\
\text { VIF }\end{array}$ \\
\hline \hline INF & 0.000292 & 14.61677 & 9.288132 \\
\hline
\end{tabular}




\begin{tabular}{llll}
\hline LOG(KURS) & 0.114553 & 1407.599 & 8.308381 \\
TRADE & 0.000112 & 10.89868 & 2.218882 \\
SB & 0.001684 & 89.37864 & 10.82707 \\
Y & 0.009126 & 59.99883 & 23.37361 \\
GI & 12.24928 & 248.2407 & 1.875649 \\
C & 18.52401 & 2986.498 & NA \\
\hline \hline
\end{tabular}

Dari hasil pengujian pada tabel diatas terlihat bahwa nilai centered Vif pada variabel suku bunga dan pertumbuhan lebih besar dari 10 sedangkan variabel inflasi, kurs, peranan perdagangan internasional dan ketimpangan pendapatan nilai Vif nya tidak lebih besar dari 10, maka dapat dikatakan bahwa persamaan yang digunakan mengandung gejala multikolinieritas (gujarati,2003).

\section{Uji Autokorelasi}

Autokorelasi pada model regresi artinya ada korelasi antar anggota sampel yang diurutkan berdasarkan waktu saling berkorelasi. Untuk mengetahui adanya autokorelasi dalam suatu model regresi dilakukan melalui pengujian metode Breusch Godfrey atau LM (lagrange multiplier) test. Hasil uji autokorelasi pada model persamaan pertama dapat dilihat pada tabel berikut :

Breusch-Godfrey Serial Correlation LM Test:

\begin{tabular}{llll}
\hline \hline F-statistic & 0.733642 & Prob. F(2,16) & 0.4956 \\
Obs*R-squared & 2.100046 & Prob. Chi-Square(2) & 0.3499 \\
\hline \hline
\end{tabular}

Test Equation:

Dependent Variable: RESID

Method: Least Squares

Date: 25/12/2019 Time: 07:22

Sample: 19902017

Included observations: 28

Presample missing value lagged residuals set to zero.

\begin{tabular}{llccc}
\hline \hline Variable & Coefficient & Std. Error & t-Statistic & Prob. \\
\hline \hline INF & 0.012620 & 0.020540 & 0.614423 & 0.5476 \\
LOG(KURS) & 0.100895 & 0.353591 & 0.285345 & 0.7790 \\
TRADE & 0.000602 & 0.010813 & 0.055630 & 0.9563 \\
SB & 0.010601 & 0.042571 & 0.249017 & 0.8065 \\
Y & 0.048841 & 0.106449 & 0.458819 & 0.6525 \\
GI & 0.893367 & 3.923681 & 0.227686 & 0.8228 \\
C & -1.763399 & 4.647889 & -0.379398 & 0.7094 \\
RESID(-1) & 0.247299 & 0.273613 & 0.903827 & 0.3795 \\
RESID(-2) & -0.296136 & 0.313225 & -0.945443 & 0.3585 \\
\hline \hline R-squared & 0.084002 & Mean dependent var & $4.92 \mathrm{E}-15$ \\
Adjusted R-squared & -0.373997 & S.D. dependent var & 0.341026 \\
S.E. of regression & 0.399742 & Akaike info criterion & 1.277719 \\
Sum squared resid & 2.556700 & Schwarz criterion & 1.716514
\end{tabular}




$\begin{array}{llll}\text { Log likelihood } & -6.971483 & \text { Hannan-Quinn criter. } & 1.399422 \\ \text { F-statistic } & 0.183411 & \text { Durbin-Watson stat } & 1.963123 \\ \text { Prob(F-statistic) } & 0.989856 & & \end{array}$

Dari Tabel hasil uji autokorelasi diatas, diketahui bahwa nilai Prob. F $(2,16)$ sebesar 0,4956 dapat juga disebut sebagai nilai probability F hitung. Nilai prob. F hitung lebih besar dari pada tingkat alpha $0,05(5 \%)$, sehingga berdasarkan uji hipotesis, Ho diterima yang artinya tidak terjadi autokorelasi.

3. Uji Heteroskedastisitas

Heteroskedastisitas terjadi pada saat residual dan nilai prediksi memiliki korelasi/ pola hubungan. Pola hubungan ini tidak hanya sebatas hubungan yang linier, tetapi dalam pola yang berbeda juga dimungkinkan. Untuk mengetahui ada tidaknya heteroskedastisitas akan dilakukan uji Glejser. Hasil Uji heteroskedastisitas dapat dilihat pada tabel berikut ini :

\begin{tabular}{llll}
\multicolumn{2}{l}{ Heteroskedasticity Test: Glejser } & & \\
\hline \hline F-statistic & 1.608596 & Prob. F(6,18) & 0.2020 \\
Obs*R-squared & 8.726065 & Prob. Chi-Square(6) & 0.1896 \\
Scaled explained SS & 5.735317 & Prob. Chi-Square(6) & 0.4535 \\
\hline \hline
\end{tabular}

Test Equation:

Dependent Variable: ARESID

Method: Least Squares

Date: 25/12/2019 Time: 07:50

Sample: 19902017

Included observations: 28

\begin{tabular}{lllll}
\hline \hline Variable & Coefficient & Std. Error & t-Statistic & Prob. \\
\hline \hline C & -0.334480 & 1.999989 & -0.167241 & 0.8690 \\
INF & 0.001020 & 0.007937 & 0.128474 & 0.8992 \\
LOG(KURS) & 0.170442 & 0.157277 & 1.083707 & 0.2928 \\
TRADE & -0.013023 & 0.004915 & -2.649819 & 0.0163 \\
SB & 0.011408 & 0.019069 & 0.598263 & 0.5571 \\
Y & 0.016332 & 0.044392 & 0.367898 & 0.7172 \\
GI & -2.481981 & 1.626355 & -1.526100 & 0.1444 \\
\hline \hline R-squared & 0.349043 & Mean dependent var & 0.273151 \\
Adjusted R-squared & 0.132057 & S.D. dependent var & 0.196413 \\
S.E. of regression & 0.182985 & Akaike info criterion & -0.327325 \\
Sum squared resid & 0.602706 & Schwarz criterion & 0.013961 \\
Log likelihood & 11.09156 & Hannan-Quinn criter. & -0.232667 \\
F-statistic & 1.608596 & Durbin-Watson stat & 2.513774 \\
Prob(F-statistic) & 0.201985 & & & \\
\hline \hline
\end{tabular}

Dari hasil uji heteroskedastisitas diatas, diketahui nilai Probability F Statistik $(6,18)$ sebesar 0,2020 lebih besar dari alpha 0,05 (5\%), maka dapat disimpulkan tidak terjadi heteroskedastisitas pada model persamaan ini. 


\section{KESIMPULAN DAN SARAN}

\section{Kesimpulan}

- Perkembangan investasi asing langsung di Indonesia pada kurun 1990-2017 menunjukkan kecenderungan fluktuatif, pada masa sebelum krisis tahun 1990-1995 nilai investasi asing langsung cenderung meningkat, namun pada tahun 1996-1998 investasi asing langsung mengalami penurunan hingga 30\% dipengaruhi kondisi perekonomian dan stabilitas politik dan keamanan di Indonesia, sedangkan pada tahun 1999-2017 investasi asing langsung berangsur meningkat.

- Pada analisis mengenai pengaruh tingkat inflasi, nilai tukar (kurs) rupiah terhadap USD, peranan perdagangan internasional terhadap PDB, suku bunga, pertumbuhan dan ketimpangan pendapatan ditemukan bahwa terdapat multikolinieritas sehingga kemudian untuk mendapatkan model analisis regresi yang tidak bias variabel pertumbuhan ekonomi yang berdasarkan nilai VIF mengalami multikolinieritas dikeluarkan dari model, dan berdasarkan hasil analisis regresi variabel inflasi, nilai tukar (kurs), peranan perdagangan internasional terhadap PDB, suku bunga dan ketimpangan pendapatan secara bersama-sama berpengaruh signifikan terhadap aliran investasi asing langsung di Indonesia pada tahun 1990-2017. Sedangkan secara parsial investasi asing langsung indonesia dipengaruhi oleh variabel peranan perdagangan internasional, nilai tukar (kurs) dan ketimpangan pendapatan.

\section{Saran}

- Dalam menetapkan strategi untuk meningkatkan aliran dana investasi asing langsung salah satunya dapat dilakukan dengan menjaga kestabilan nilai tukar rupiah terhadap dolar, serta meningkatkan perdagangan internasional. Dengan menerapkan langkah tersebut diharapkan dapat menarik minat investor asing untuk menanamkan investasinya di Indonesia.

- Untuk penelitian selanjutnya diharapkan dapat mengkaji faktor-faktor lain yang belum diteliti dalam kaitannya dengan pengaruh terhadap aliran investasi asing langsung di Indonesia serta menggunakan data-data yang lebih beragam sehingga menghasilkan informasi yang lebih banyak dalam membantu pihak yang berkepentingan.

\section{DAFTAR PUSTAKA}

Ajija, R.Shochrul, Sari, W.Dyah, Setianto, H.Rahmat, Primanti, R.Martha, 2011, Cara Cerdas Menguasai Eviews, Penerbit Salemba Empat, Jakarta.

Ariefianto., \& Doddy. (2012). Ekonometrika Esensi dan Aplikasi dengan Menggunakan Eviews. Erlangga, Jakarta.

Bellinger, WK. (2007). The Economic Analysis of Public Policy, London Routledge. 
Dewata, K., \& Yogiswara,W. (2013). Pengaruh Total Ekspor, Libor, dan Upah Tenaga Kerja terhadap Investasi Asing langsung di Indonesia. jurnal Ekonomi Pembangunan, Universitas Udayana, 2(8).

Effendi, N., \& Soemantri, F, M. (2003). Foreign direct investment and regional economics growth in Indonesia: A panel data study. Working paper in economics and development studies. http://www.lp3e-unpad.org.

Germidis, D. (1977). Transfer of technology by multinational corporations. Development centre of organization for economic cooperation and development. Paris.

Harniati. (2007). Tipologi Kemiskinan dan Kerentanan Berbasis Agro Ekonomi dan Implikasinya pada Kebijakan Pengangguran Kemiskinan. Tesis, Institut Pertanian Bogor, Bogor.

Kishi, M. (2003), Foreign Direct Investment by Japanese Firms \& Corporate Governance Relation of Monetary Policies of China, Korea \& Japan, Journal of Asian Economics 13(1), pp 731-748.

Nanga, M. (2006). Dampak Desentralisasi Fiskal Terhadap Kemiskinan di Indonesia, Suatu Analisi Simulasi Kebijakan. Tesis, Institut Pertanian Bogor, Bogor).

Setiawan, G. (2002). The Impact of FDI on Indonesia's Economic Growth KDI Sektoral of Public Policy \& Management, Master Thesis.

Soleh, A., \& Maryoni, H. S. (2017). Analisis Sektor Ekonomi Unggulan Dan Hubungannya Dengan Kesempatan Kerja dan Investasi di Kabupaten Batanghari. Jurnal Ekonomi-Qu, $7(1)$.

Todaro MP, Smith SC, 2006, Pembangunan Ekonomi Edisi Kesembilan (Alih Bahasa oleh Haris Munandar dan Puji A.L), Jakarta, Erlangga.

UNCTAD (2004), Prospects for FDI Flows, TNC Strategies \& Promotion Policies;2004-2007. 